\title{
DESCRIPTION OF UKRAINIAN STUDENTS' AWARENESS OF PERSONAL HEALTH PROTECTION AND THEIR LIFESTYLE STUDY RESULTS
}

\section{Zhdanova O. V.}

\section{INTRODUCTION}

Health of students as the nation's intellectual and labor potential is an important challenge for any country ${ }^{1}$. Scientists around the world study this issue. $^{2}$ The increasingly stringent requirements for specialist training and qualification level in higher educational institutions result in excessive strain for students and deterioration of their health. For instance, physical and psychological/emotional strain results in exhaustion of adaptation reserves of the nervous, endocrine and immune systems, thus increasing the risk of diseases ${ }^{3},{ }^{4}$. Researchers state that students' health deteriorates significantly over the time of their university studies and that by graduation time only $20 \%$ of the graduates may be considered to be apparently healthy people ${ }^{5}$.

At the same time, lifestyle factors also impact the health of population including students. Pursuant to $\mathrm{WHO}^{67}$, this factor contributes to $50-55 \%$ of human health factors. In particular, the affecting factors include unhealthy nutrition, recurrent stress, labor, substandard domestic and economic

1 Hrebnyak N.P. Students' Health and Lifestyles / N.P. Hrebnyak, V.P. Hrebnyak, V.V. Mashinistov // Issues of Social Hygiene, Health Care and Medical Sphere History. - 2007. № 4. - P. 33-37.

${ }^{2}$ Hooper L., Abdelhamid A., Moore H.J., Douthwaite W., Skeaff C.M., Summerbell C.D. Effect of reducing total fat intake on body weight: systematic review and meta-analysis of randomised controlled trials and cohort studies. British Medical Journal, 2012. no. 12. P. 12-15.

${ }^{3}$ Baklykova A.V. Health and Lifestyles of Medical Students // Molodoy Ucheniy - 2010. № 5. V. 2. - P. 205-207.

4 Sadvakasov T.M. Comparative Characteristic of Young Persons' Lifestyles // T.M. Sadvakasov, Sh.D. Dzhaketayeva, G.A. Zhanalina, Z.A. Aldanova, K.T. Abdrakhmanov, T.S. Sergaliyev, D.B. Kulov // Medical Science and Ecology. - 2015. - № 1(74). - P. 46-47.

5 Shagina I.R. Impact of Studies on Students' Health // Astrakhan Medical Journal. 2010. - № 2. - P. 26-29.

${ }^{6}$ Fats and fatty acids in human nutrition: report of an expert consultation. Food and Agricultural Organization of the United Nations / FAO Food and Nutrition. - Rome, Italy. 2010. - P. 91.

${ }^{7}$ Diet, nutrition and the prevention of chronic diseases: report of a Joint WHO/FAO Expert Consultation. World Health Organization - WHO Technical Report Series, No. 916. - Geneva, Switzerland, -2003. 
conditions, physical inactivity, tobacco, alcohol and drug abuse, uncontrolled use of medications and low cultural level.

The research of students' health displayed that health deterioration directly depends on their lifestyles ${ }^{8,9}$.

According to O.S. Popkova ${ }^{10}$, popular students' unhealthy habits especially alert the researchers with regard to alcohol use, which is attributed to young females $(73 \%)$ even more often than to young males $(66 \%)$. Typically, though, young females use low-alcohol beverages periodically, while young males use stronger drinks and do it significantly more often. Smoking habit is an equally hazardous phenomenon in this environment (77\% of young females and $85 \%$ of young males, with $50 \%$ of regular female smokers and $76 \%$ of male smokers). Based on the poll, more than $38 \%$ of young males and $26 \%$ of young females experimented with narcotic substances, and $11 \%$ of young males and $2 \%$ of young do it on a regular basis. None of the subjects admitted parenteral use of narcotic substances. Also, a high level of gastrointestinal tract diseases (41\%) was detected in student community due to substantial malnutrition. Students are far from leading healthy lives. This is confirmed by statistics stating that students dedicate their leisure time either to friends or to personal computers ${ }^{11}$. At the same time, the students are informed wrongly about sexual intercourse and contraception methods. This increases risks of unawareness and lack of knowledge about medical consequences of abortions ${ }^{12}$.

Physical training and sports represent the main elements of healthy lifestyle. The research results demonstrate ${ }^{13}$ that $49 \%$ of young males and $64 \%$ of young females exercise once or twice a week and $29 \%$ and $19 \%$, correspondingly, three or four times a week. The main motivations stated by the students as reasons behind their sports exercise include the motivation to improve own health $(57 \%)$, to gain healthy looks $(51 \%)$, to be more fit

\footnotetext{
${ }^{8}$ Harkusha S.V. Description of Contemporary Youths Health State in Ukraine. Chernihiv Shevchenko National Pedagogical University's Journal. Series on pedagogical science and physical culture2013;1(107):92-5.

${ }^{9}$ Ponomaryova L.A. Analysis of Medical Students Health Level / L.A. Ponomaryova, S.I. Dvoynikov // Family Health, XXI Century: materials of the VI th scientific international conference - Perm', 2002. - p. 111-112.

${ }_{10}$ Popkova O.S. Social and Hygienic Features in Health Maintaining Behavior of Studentds // Molodoy Ucheniy. - 2015. - № 6.4 - p. 44-46. - URL https://moluch.ru/archive/ 86/16378/ (application date: 09.11.2019).

${ }^{11}$ Zhdanova O.V. Level of Internet Dependence of Student Use (based on sociological study) / O.V. Zhdanova, G.O. Slabkiy // Ukraine. Zdorovya Natsiyi. 2019. - № 2 - - P. 55-58

12 Baklykova A.V. Health and Lifestyle of Medical Students. Molodoy Ucheniy. 2010;5:205-7.

${ }^{13}$ Ushakova Ya.V. Health of Students and Factors of it Formastion /Ya.V. Ushakova // Nizhegorodskiy Lobachevskiy University Journal 2017. - №4 - p.197-202
} 
(47\%), to be in better shape (49\%), to get rid of fatigue and increase work performance (26\%). However, only 39\% perceive physical exercise and sports as elements of healthy way of life.

The issue of maintaining and strengthening student youths' health is a complex and multilayered issue. Due to the changes in today's economic realities, this problem calls for a new approach to attack it. Health sector has to find new forms of medical assistance provision including the design of efficient methods of mass preventive examinations and development of healthy culture in students stimulating them to treat their health as their valuable asset ${ }^{14}$.

Human psychology is built in such a way that while they are young and healthy they hardly care about their health. This approach continues until they feel specific symptoms of health problems. The setup of health care for students shall take into account that students are increased risk social group related to age-related issues, adaptation to physiological and anatomical changes, high psycho-emotional and intellectual stress, adaptation to new living conditions and educational environment and shaping of interpersonal relationships.

The analysis of published research data related to students' attitude towards their health witnesses certain problems in this area. The key issues are: unhealthy habits (alcohol, drugs and tobacco abuse), untimely meals, lack of sleep, insufficient physical activity, etc. However, when assessing their health, most students state they have good health and almost a quarter of respondents state they have average health.

At the same time, it is important to observe a number of healthy life conditions to maintain and strengthen the students' health. One of the mandatory requirements for healthy life is active lifestyle and systematic physical exercise corresponding to gender, age and health condition, as well as healthy nutrition and refusal from unhealthy habits.

\section{Description of student youths' knowledge of healthy lifestyle and safe behavior}

The research was based on sociological study of 446 students from different departments and of different years if Uzhhorod National University and Ukrainian Dental Academy. The poll covered 217 medical department students (102 young males and 115 young females), 105 dental department students (44 young males and 61 young females) and 124 students of non-

${ }^{14}$ Zhuravlyova I.V., editor. Health of Students: Sociological Analysis. RAS Institute of Sociology. Moscow; 2012. P. 252. 
medical departments (67 young males and 57 young females). The research used both the sociological and statistics research methods.

A special questionnaire was prepared for the sociological research. The questionnaire was reviewed and approved by the resolution of biotic commission of Uzhhorod National University on May 14. 2019, minutes № 2. The questionnaire included an introduction part with questions about the department and academic curriculum, a set of questions for students' self-assessment of their health and a set of questions to assess their actual way of life including nutrition, sleep, physical activity, alcohol use and safe sexual behavior. The students filled out the questionnaires in their classes after the end of lectures. The goal of research was explained to the respondents. The time of questionnaires filling was up to 20 minutes. The questionnaires were handed to the researcher.

The research results were entered into consolidated tables and relative percentage results were calculated.

During the sociological study, the following principles were observed: Helsinki Declaration adopted by the General Assembly of the World Health Organization (1964-2000), Convention of EC on Human Rights and Biomedicine (1997) of the European Convention on Vertebrate Animals Use for Experiments (1986), associated provisions of WHO, International Council of Medical Scientific Societies, International Medical Ethics Code (1983) and the legislation of Ukraine. No students under 18 were invited to take part in the research.

At the first stage of the research, the student youths' awareness of healthy life, safe behavior and prevention of non-communicable and communicable diseases including HIV were studied. The results of polling are shown in table 1

The analysis of data from table 1 indicates that the polled students of all departments marked personal awareness of healthy life knowledge as sufficiently high and the same attributes to personal health maintenance and protection. Out of all questions asked to the students they marked their knowledge as sufficient and satisfactory at least at $70 \%$ level.

The next step of the research was aimed at the study of actual level of students' knowledge of healthy lifestyle, safe behavior and health maintaining techniques. The research used a specialized questionnaire. The collected research results are stated in table 2 . 
Table 1

\section{Level of students' self-assessment of their knowledge of maintaining and improving personal health}

\begin{tabular}{|c|c|c|c|c|c|c|c|}
\hline \multicolumn{2}{|l|}{ Question } & \multicolumn{2}{|c|}{$\begin{array}{c}\text { Medical } \\
\text { Department, p-217 }\end{array}$} & \multicolumn{2}{|c|}{$\begin{array}{c}\text { Dental } \\
\text { Department } \\
\text { p-105 }\end{array}$} & \multicolumn{2}{|c|}{$\begin{array}{c}\text { Other } \\
\text { Departments } \\
\text { p-124 }\end{array}$} \\
\hline & & abs & $\%$ & abs & $\%$ & abs & $\%$ \\
\hline \multirow{3}{*}{$\begin{array}{l}\text { Components of } \\
\text { healthy life }\end{array}$} & 1 & 94 & 43.32 & 31 & 25.00 & 17 & 16.19 \\
\hline & 2 & 93 & 42.86 & 86 & 69.35 & 69 & 65.71 \\
\hline & 3 & 30 & 13.82 & 7 & 5.65 & 19 & 18.09 \\
\hline \multirow{3}{*}{$\begin{array}{l}\text { Rational nutrition } \\
\text { principles }\end{array}$} & 1 & 32 & 14.75 & 29 & 23.39 & 15 & 14.29 \\
\hline & 2 & 144 & 66.36 & 90 & 72.58 & 73 & 69.52 \\
\hline & 3 & 41 & 18.89 & 5 & 4.05 & 17 & 16.19 \\
\hline \multirow{3}{*}{$\begin{array}{l}\text { Physical exercise } \\
\text { standards }\end{array}$} & 1 & 35 & 16.13 & 21 & 16.94 & 15 & 14.29 \\
\hline & 2 & 145 & 66.82 & 96 & 77.42 & 45 & 42.86 \\
\hline & 3 & 37 & 17.05 & 7 & 5.65 & 45 & 42.86 \\
\hline \multirow{3}{*}{$\begin{array}{l}\text { Stress prevention } \\
\text { principles }\end{array}$} & 1 & 24 & 11.06 & 12 & 9.68 & 11 & 10.48 \\
\hline & 2 & 144 & 66.36 & 95 & 76.61 & 77 & 73.33 \\
\hline & 3 & 49 & 22.58 & 17 & 13.71 & 17 & 16.19 \\
\hline \multirow{3}{*}{$\begin{array}{l}\text { HIV infection } \\
\text { prevention }\end{array}$} & 1 & 52 & 23.96 & 42 & 33.87 & 27 & 25.71 \\
\hline & 2 & 135 & 62.21 & 67 & 54.03 & 69 & 65.71 \\
\hline & 3 & 29 & 13.36 & 15 & 12.09 & 9 & 8.57 \\
\hline \multirow{3}{*}{$\begin{array}{c}\text { Sexually } \\
\text { transmitted } \\
\text { diseases } \\
\text { prevention }\end{array}$} & 1 & 84 & 38.71 & 31 & 25.00 & 30 & 28.57 \\
\hline & 2 & 121 & 55.76 & 84 & 67.74 & 64 & 60.95 \\
\hline & 3 & 12 & 5.53 & 9 & 7.26 & 11 & 10.48 \\
\hline \multirow{3}{*}{$\begin{array}{l}\text { Health damage } \\
\text { due to tobacco use }\end{array}$} & 1 & 34 & 15.67 & 29 & 23.39 & 17 & 16.19 \\
\hline & 2 & 154 & 70.97 & 90 & 72.58 & 73 & 69.52 \\
\hline & 3 & 29 & 13.36 & 5 & 66.36 & 15 & 14.29 \\
\hline \multirow{3}{*}{$\begin{array}{l}\text { Health damage } \\
\text { due to alcohol use }\end{array}$} & 1 & 45 & 20.74 & 31 & 25.00 & 21 & 20.00 \\
\hline & 2 & 141 & 64.98 & 86 & 69.35 & 73 & 69.52 \\
\hline & 3 & 31 & 14.29 & 7 & 5.65 & 11 & 10.48 \\
\hline \multirow{3}{*}{$\begin{array}{c}\text { Health damage } \\
\text { due to narcotics } \\
\text { use }\end{array}$} & 1 & 44 & 20.28 & 32 & 25.81 & 19 & 18.09 \\
\hline & 2 & 116 & 53.46 & 91 & 73.39 & 66 & 62.86 \\
\hline & 3 & 57 & 26.27 & 11 & 8.87 & 20 & 19.05 \\
\hline \multirow{3}{*}{$\begin{array}{l}\text { Unwanted } \\
\text { pregnancy } \\
\text { prevention }\end{array}$} & 1 & 94 & 43.32 & 51 & 41.13 & 24 & 19.35 \\
\hline & 2 & 110 & 50.69 & 62 & 50.00 & 72 & 58.06 \\
\hline & 3 & 13 & 5.99 & 11 & 8.87 & 9 & 7.26 \\
\hline
\end{tabular}

Note: 1-sufficient, 2 - satisfactory, 3 - uninformed. 
Table 2

Students' awareness of healthy lifestyle and safe behavior

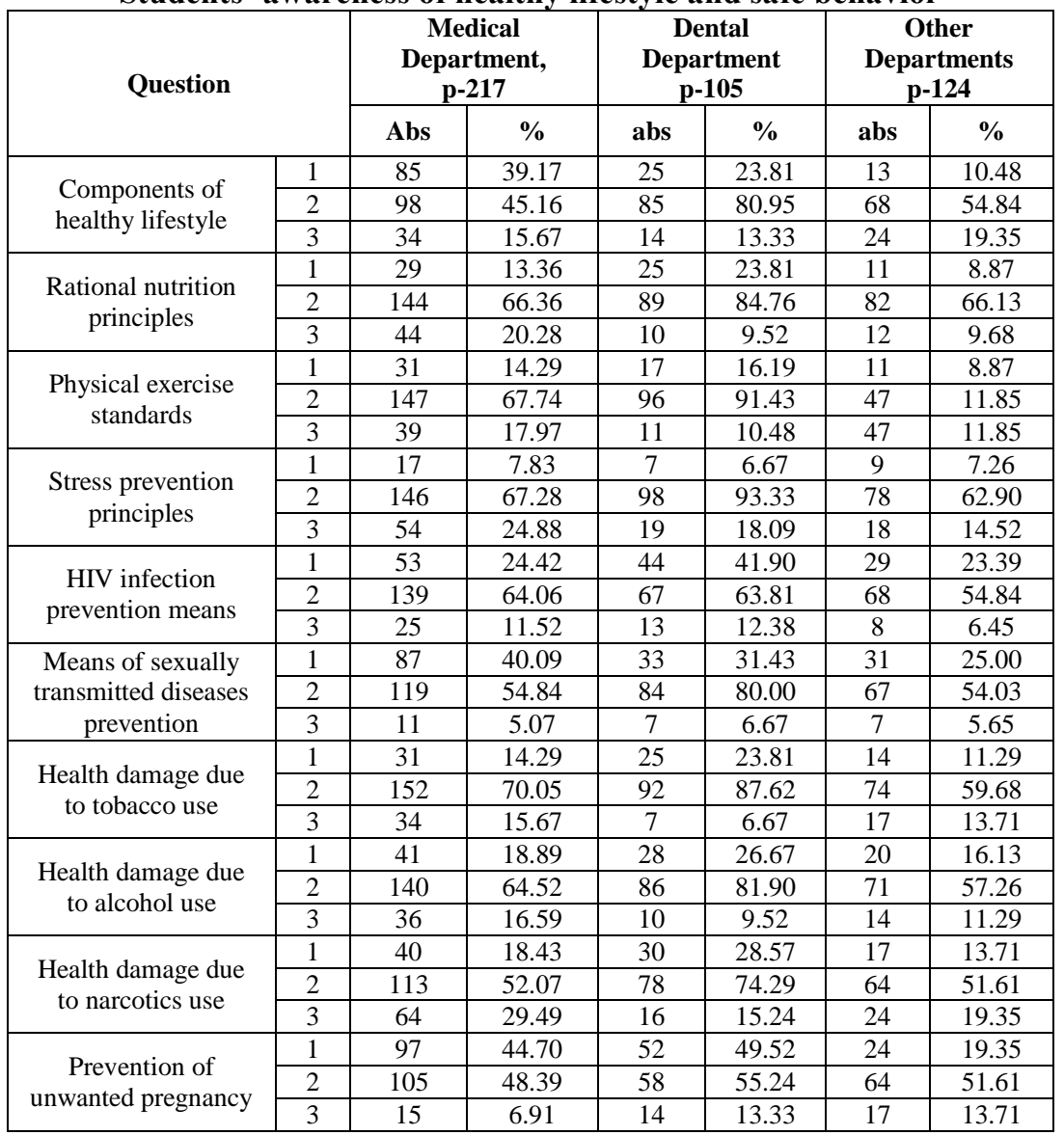

Note: 1-sufficient, 2 - satisfactory, 3 - wrong answer.

The results of the research aimed at the study of actual students' knowledge of healthy lifestyle, safe behavior and health maintaining technologies stated in table 2 indicated a rather high level of students' awareness of the said issues. The actual awareness level is lower by a statistically negligible value as compared to their self-assessment. The awareness level of medical and dental department students is higher that non-medical department students. 
In general, the research results indicate a rather high level of student knowledge of issues related to healthy lifestyle, safe behavior and health maintaining technologies.

\section{Description of lifestyle and behavior aimed at maintaining and improving personal health}

Thereafter, certain components of the polled students' lifestyle were studied. These related to the nutrition of the students, their physical exercise level and sleep duration. The results are stated in table 3.

The results witness the fact that a significant number of students lead lives, which don't help neither maintain nor improve personal health. For instance, $52.27 \%$ of young males of the dental department, $42.11 \%$ of young female students and $40.29 \%$ of young male students of non-medical departments sleep less than 4 hours a day. Malnutrition with regard to the meals timing, as well as to foods range and quality of food products applies to more than $70 \%$ of students of all departments regardless of gender with the exception of young female students of the medical department who violate the nutrition rules in $49.56 \%$ of instances. At the same time, more than $60 \%$ of the polled students drink sugar-containing carbonated beverages on a daily basis.

All the polled students have insufficient physical exercise. Less than 25\% of the polled students exercise daily, except of young males from the dental department, where $27.27 \%$ of the polled students do physical exercise daily. Less than $30 \%$ of all polled students regardless of gender or faculty go to the gym or swimming pool. At the same time, more than $75 \%$ of the polled students walk less than 5000 steps daily. The least number of steps is covered by young females from the dental department. This group's percentage covering more than 5000 steps daily equals $11.48 \%$. At the same time, the people spending more than 2 hours using their computers daily amount to more than $40 \%$.

The next step of the study was the sexual behavior research and condom use as HIV and STD infections prevention as well as unwanted pregnancy avoidance. The results are shown in table 4 .

The analysys of data from table 4 indicates that more than $70 \%$ of the polled students over the 12 months prior to the poll had sexual intercourse. The overwhelming majority of the polled students have one intercourse partner. Dental department students (34.38\% of young males) have at least three intercourse partners and the same result was claimed by $15.79 \%$ of young males from non-medical departments. 
Table 3

Selected data on the polled students' lifestyles

\begin{tabular}{|c|c|c|c|c|c|c|c|}
\hline \multicolumn{2}{|l|}{ Description } & \multicolumn{2}{|c|}{$\begin{array}{c}\text { Medical } \\
\text { Department }\end{array}$} & \multicolumn{2}{|c|}{$\begin{array}{c}\text { Dental } \\
\text { Department }\end{array}$} & \multicolumn{2}{|c|}{$\begin{array}{c}\text { Other } \\
\text { Departments }\end{array}$} \\
\hline & & abs & $\%$ & abs & $\%$ & abs & $\%$ \\
\hline \multirow{2}{*}{$\begin{array}{c}\text { At least } 7 \text { hours of } \\
\text { sleep, daily }\end{array}$} & 1 & 27 & 26.47 & 11 & 25.00 & 24 & 35.82 \\
\hline & 2 & 31 & 26.96 & 14 & 22.95 & 21 & 36.84 \\
\hline \multirow{2}{*}{$\begin{array}{l}\text { Less than } 4 \text { hours of } \\
\text { sleep, daily }\end{array}$} & 1 & 39 & 38.24 & 23 & 52.27 & 27 & 40.29 \\
\hline & 2 & 27 & 23.48 & 21 & 34.43 & 24 & 42.11 \\
\hline \multirow{2}{*}{ Regular meals } & 1 & 15 & 14.71 & 7 & 15.91 & 14 & 20.89 \\
\hline & 2 & 31 & 26.96 & 12 & 19.67 & 16 & 28.07 \\
\hline \multirow{2}{*}{$\begin{array}{l}\text { Foods range and } \\
\text { quality tracking }\end{array}$} & 1 & 11 & 10.78 & 7 & 15.91 & 14 & 20.89 \\
\hline & 2 & 19 & 16.52 & 12 & 19.67 & 16 & 28.07 \\
\hline \multirow{2}{*}{$\begin{array}{c}\text { Haphazard foods } \\
\text { selection }\end{array}$} & 1 & 87 & 85.29 & 37 & 84.09 & 53 & 79.10 \\
\hline & 2 & 57 & 49.56 & 49 & 80.33 & 41 & 71.93 \\
\hline \multirow{2}{*}{$\begin{array}{c}\text { Daily use of sweet } \\
\text { carbonated } \\
\text { beverages }\end{array}$} & 1 & 69 & 67.65 & 32 & 72.73 & 42 & 62.69 \\
\hline & 2 & 71 & 61.74 & 47 & 77.05 & 44 & 77.19 \\
\hline \multirow{2}{*}{$\begin{array}{l}\text { Daily physical } \\
\text { exercise }\end{array}$} & 1 & 19 & 18.63 & 12 & 27.27 & 13 & 19.40 \\
\hline & 2 & 25 & 21.74 & 10 & 16.39 & 9 & 15.79 \\
\hline \multirow{2}{*}{$\begin{array}{l}\text { At least a weekly } \\
\text { visit to the gym }\end{array}$} & 1 & 21 & 20.59 & 11 & 25.00 & 11 & 16.42 \\
\hline & 2 & 32 & 27.83 & 12 & 19.67 & 10 & 17.54 \\
\hline \multirow{2}{*}{$\begin{array}{l}\text { At least a weekly } \\
\text { visit to the } \\
\text { swimming pool }\end{array}$} & 1 & 17 & 16.67 & 12 & 27.27 & 7 & 10.45 \\
\hline & 2 & 21 & 18.26 & 7 & 11.48 & 11 & 19.29 \\
\hline \multirow{2}{*}{$\begin{array}{l}\text { More than } 2 \text { hours } \\
\text { spent daily with PC }\end{array}$} & 1 & 46 & 45.09 & 21 & 47.73 & 24 & 35.82 \\
\hline & 2 & 51 & 44.35 & 27 & 44.26 & 27 & 47.37 \\
\hline \multirow{2}{*}{$\begin{array}{l}\text { At least one monthly } \\
\text { visit to a drama } \\
\text { theater }\end{array}$} & 1 & 4 & 3.92 & 2 & 4.55 & 2 & 2.99 \\
\hline & 2 & 3 & 2.61 & 3 & 4.92 & 7 & 12.28 \\
\hline \multirow{2}{*}{$\begin{array}{l}\text { Covers no less than } \\
5000 \text { steps daily }\end{array}$} & 1 & 23 & 22.55 & 9 & 20.45 & 12 & 17.91 \\
\hline & 2 & 20 & 17.39 & 7 & 11.48 & 14 & 24.56 \\
\hline
\end{tabular}

More than $70 \%$ of all polled students use condoms at all times except for young female students of dental department, where $63.26 \%$ use condoms all the time. During the latest intercourse the students who failed to use condoms most frequently belonged to the medical department $(23.26 \%$, young males) and to non-medical departments (21.88\% young males and 18.37 young females). The said statistics of condom use witness the fact that a significant part of students fails to follow safe sex practices and therefore they are not protected from HIV, STD or unwanted pregnancy. Taking into account the unsafe sexual behavior, depending on the department and gender, from 8.25 to 25.00 percent of the polled students passed HIV tests. 
Taking into account the negative impact of alcohol abuse and other researchers' data on high alcohol use level we had to study the information on students' alcohol intake at this stage of the country's social an economical development and higher education system development in the country. We covered the issues of determining the students' percentage who used alcohol, including the alcohol use over the 30 days preceding this poll, we asked what alcohol beverages the students prefer, enquired about the frequency of alcohol intake and studied the negative impacts of the alcohol use. The research results are quoted in table 5 .

Table 4

Sex-related behavior and condom use practice

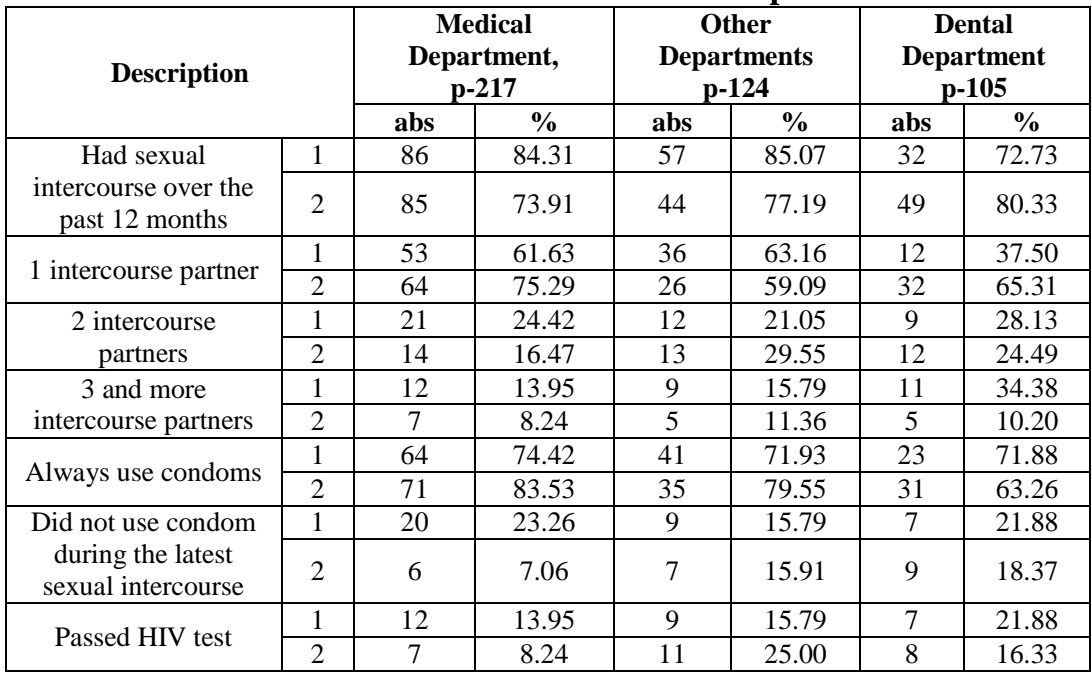

Note: 1-young males, 2 - young females.

The analysis of data from table 5 shows that all of the polled students have alcohol use experience. More than $90 \%$ of the polled students of the medical department and young males from non-medical departments drank alcohol over the past 30 days. The lowest percentage of alcohol users over the past 30 days belonged to the dental department: $68.18 \%$ of young males and $60.66 \%$ of young females. 
Table 5

The history of alcohol beverages intake

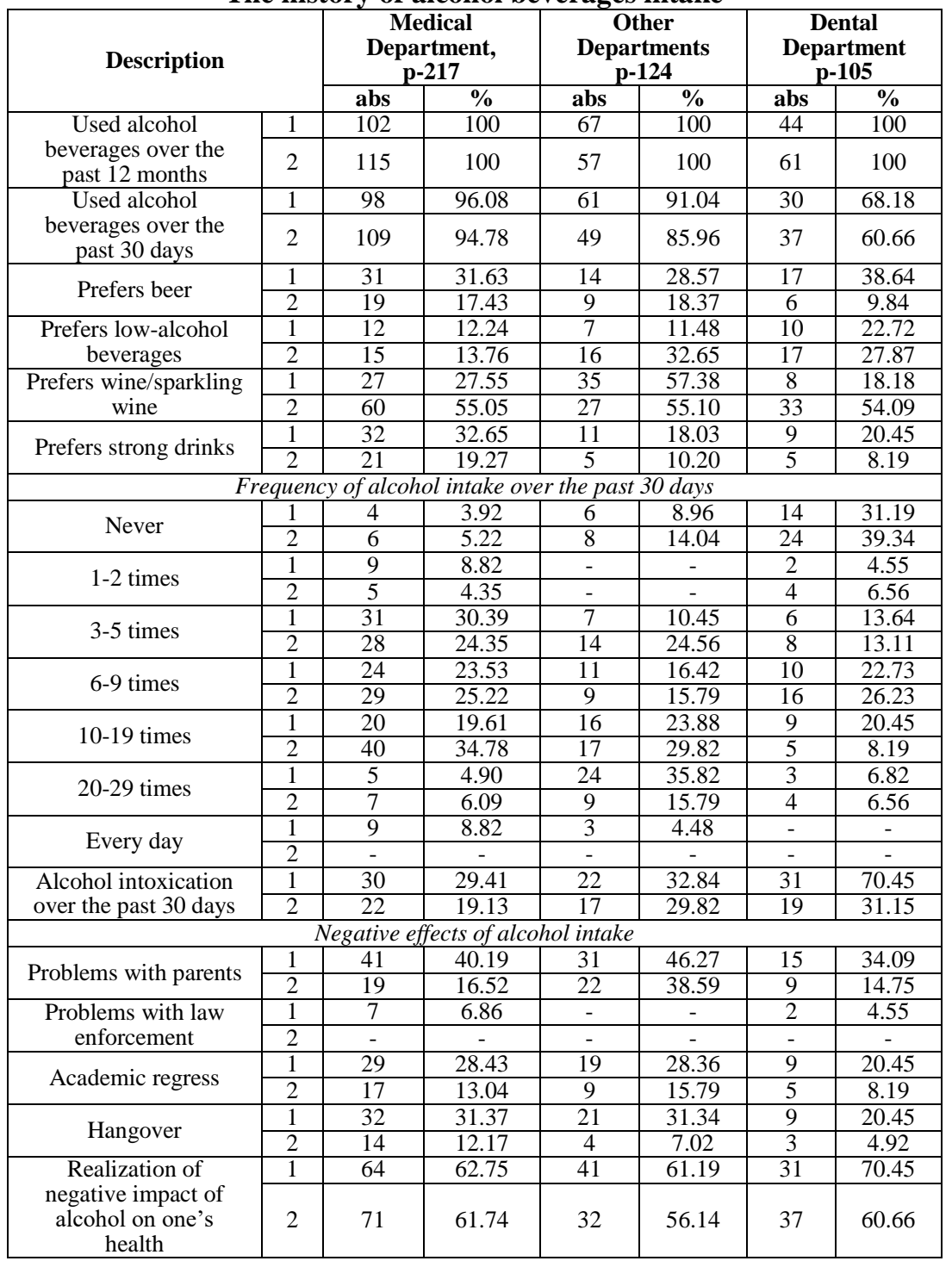

Note: 1-young males, 2 - young females. 
The following alcohol type preferences were discovered by gender and department. Young males from the medical department prefer beer (31.63\%) and strong drinks $(32.65 \%)$, while young females prefer wine/sparkling wine $(55.05 \%)$ and strong drinks (19.27\%). Young male students of dental department prefer beer (38.64\%) and low-alcohol beverages $(22.72 \%)$, and young females - wine/sparkling wine $(54.09 \%)$ and low-alcohol beverages $(27.87 \%)$. Young male students of non-medical departments prefer wine/sparkling wine $(57.38 \%)$ and beer $(28.57 \%)$, and young females wine/sparkling wine $(55.10 \%)$ and low-alcohol beverages $(32.65 \%)$.

As for the frequency of alcohol intake, the data indicate that the most frequent alcohol users (young males) study at the medical department 3-5 times a month (30.39\%), and young females - 10-19 times (34.78\%). Both, young males and young females from the dental department use alcohol most frequently - 6-9 times a month: $22.73 \%$ and $26.23 \%$, correspondingly. Young male students of non-medical departments use alcohol most frequently: 20-29 times a month (35.82\%), and young females: 10-19 times (29.82\%). At the same time, $8.82 \%$ of young males from the medical department and $4.48 \%$ from non-medical departments use alcohol on a daily basis.

Out of those who used alcohol over the past 30 days, the most frequently intoxicated ones were young male students $(70.45 \%)$ and young females $(31.15 \%)$ who study at the dental department and young male students from non-medical departments $(32.84 \%)$.

The students have certain negative effects of alcohol abuse. These primarily include problems with parents, hangover and academic regress. A few students had problems with the police.

At the same time, more than half of the polled students realize the negative effect of alcohol on health and this includes $70.65 \%$ of young male students and $60.66 \%$ of young female students who study at the dental department, $62.75 \%$ of young male students from the medical department and $61.19 \%$ of young male students who study at non-medical departments.

The next step of our research was the study of student's reasons for alcohol use. The results are shown in table 6 .

Based on the data from table 6 it is possible to state that for medical department students in $37.39 \%$ of cases (young females) the cause of alcohol use is certain events celebration, while for $18.63 \%$ of young male students of the same department the cause is riddance of problems. For $34.09 \%$ of young male students who study at the dental department the use of alcohol is a factor of having a good time, while for young female students of the same department the cause is the celebration of certain events in $24.59 \%$ of cases. The students of non-medical departments most often use alcohol to celebrate certain events: this is true for $20.89 \%$ of young males and $35.09 \%$ of young females. Roughly $10 \%$ of the subjects use alcohol socially. 
Table 6

The causes of alcohol beverages use

\begin{tabular}{|c|c|c|c|c|c|c|c|}
\hline \multicolumn{2}{|l|}{ Description } & \multicolumn{2}{|c|}{$\begin{array}{c}\text { Medical } \\
\text { Department, } \\
\text { p-217 }\end{array}$} & \multicolumn{2}{|c|}{$\begin{array}{c}\text { Dental } \\
\text { Department } \\
\text { p-105 }\end{array}$} & \multicolumn{2}{|c|}{$\begin{array}{c}\text { Other } \\
\text { Departments } \\
\text { p-124 }\end{array}$} \\
\hline & & abs & $\%$ & abs & $\%$ & abs & $\%$ \\
\hline \multirow{2}{*}{ Get rid of problems } & 1 & 19 & 18.63 & 6 & 13.64 & 7 & 10.45 \\
\hline & 2 & 8 & 6.96 & 5 & 8.19 & 3 & 5.26 \\
\hline \multirow{2}{*}{ Feel relaxed } & 1 & 17 & 16.67 & 5 & 11.36 & 6 & 8.96 \\
\hline & 2 & 12 & 10.43 & 7 & 11.48 & 7 & 12.28 \\
\hline \multirow{2}{*}{ Feel joy } & 1 & 9 & 8.82 & 5 & 11.36 & 9 & 13.43 \\
\hline & 2 & 11 & 9.56 & 7 & 11.48 & 4 & 7.02 \\
\hline \multirow{2}{*}{ Have fun } & 1 & 14 & 13.73 & 15 & 34.09 & 14 & 20.89 \\
\hline & 2 & 19 & 16.52 & 17 & 27.87 & 8 & 14.04 \\
\hline \multirow{2}{*}{ Feel friendly } & 1 & 7 & 6.86 & 3 & 6.82 & 7 & 10.45 \\
\hline & 2 & 13 & 11.30 & 5 & 8.19 & 4 & 7.02 \\
\hline \multirow{2}{*}{$\begin{array}{c}\text { To keep other } \\
\text { people's company }\end{array}$} & 1 & 12 & 11.76 & 3 & 6.82 & 7 & 10.45 \\
\hline & 2 & 9 & 7.83 & 5 & 8.19 & 4 & 7.02 \\
\hline \multirow{2}{*}{$\begin{array}{c}\text { To celebrate certain } \\
\text { events }\end{array}$} & 1 & 15 & 14.71 & 7 & 15.91 & 14 & 20.89 \\
\hline & 2 & 43 & 37.39 & 15 & 24.59 & 20 & 35.09 \\
\hline \multirow{2}{*}{ Physical need } & 1 & 9 & 8.82 & - & - & 3 & 4.48 \\
\hline & 2 & - & - & - & - & - & - \\
\hline
\end{tabular}

Note: 1-young males, 2 - young females.

At the end of the study, the issue of affordability/availability of cigarettes, alcohol and drugs was studied. Table 7 states the results based on "easily available/affordable" and "rather easily available/affordable" answers.

Table 7

Availability of cigarettes, alcohol and drugs (sum total of "easily available/affordable" and "rather easily available/affordable" answers)

\begin{tabular}{|c|c|c|c|c|c|c|c|}
\hline \multirow{2}{*}{\multicolumn{2}{|c|}{ Description }} & \multicolumn{2}{|c|}{$\begin{array}{c}\text { Medical } \\
\text { Department, } \\
\text { p-217 }\end{array}$} & \multicolumn{2}{|c|}{$\begin{array}{c}\text { Dental } \\
\text { Department } \\
\text { p-105 }\end{array}$} & \multicolumn{2}{|c|}{$\begin{array}{c}\text { Other } \\
\text { Departments } \\
\text { p-124 }\end{array}$} \\
\hline & & abs & $\%$ & abs & $\%$ & abs & $\%$ \\
\hline \multicolumn{2}{|l|}{1} & 2 & 3 & 4 & 5 & 6 & 7 \\
\hline \multirow{2}{*}{ Cigarettes } & 1 & 102 & 100.0 & 44 & 100 & 67 & 100 \\
\hline & 2 & 115 & 100.0 & 61 & 100 & 57 & 100 \\
\hline \multirow{2}{*}{ Beer } & 1 & 102 & 100.0 & 44 & 100 & 67 & 100 \\
\hline & 2 & 115 & 100.0 & 61 & 100 & 57 & 100 \\
\hline \multirow{2}{*}{ Wine, sparkling wine } & 1 & 102 & 100.0 & 44 & 100 & 67 & 100 \\
\hline & 2 & 115 & 100.0 & 61 & 100 & 57 & 100 \\
\hline \multirow{2}{*}{ Low-alcohol beverages } & 1 & 97 & 95.10 & 44 & 100 & 67 & 100 \\
\hline & 2 & 115 & 100.0 & 61 & 100 & 57 & 100 \\
\hline \multirow{2}{*}{ Strong alcohol } & 1 & 100 & 98.04 & 44 & 100 & 67 & 100 \\
\hline & 2 & 109 & 94.78 & 61 & 100 & 57 & 100 \\
\hline
\end{tabular}


Continuation of Table 7

\begin{tabular}{|c|c|c|c|c|c|c|c|}
\hline $\mathbf{1}$ & $\mathbf{2}$ & $\mathbf{3}$ & $\mathbf{4}$ & $\mathbf{5}$ & $\mathbf{6}$ & $\mathbf{7}$ & $\mathbf{8}$ \\
\hline \multirow{2}{*}{ Marijuana or hashish } & 1 & 41 & 40.19 & 15 & 34.09 & 14 & 20.89 \\
\cline { 2 - 8 } & 2 & 21 & 18.27 & 11 & 18.03 & 7 & 12.28 \\
\hline \multirow{2}{*}{ Amphetamine } & 1 & 32 & 31.37 & 13 & 29.55 & 12 & 17.91 \\
\cline { 2 - 8 } & 2 & 19 & 16.52 & 7 & 11.47 & 5 & 8.77 \\
\hline \multirow{2}{*}{$\begin{array}{c}\text { LCD or other } \\
\text { hallucinogens }\end{array}$} & 1 & 30 & 29.41 & 11 & 25.00 & 13 & 19.40 \\
\hline \multirow{2}{*}{$\begin{array}{c}\text { Tranquilizers } \\
\text { or other sedatives }\end{array}$} & 1 & 15 & 13.04 & 12 & 19.67 & 8 & 14.04 \\
\hline \multirow{2}{*}{ Ecstasy } & 2 & 13 & 33.33 & 9 & 20.45 & 11 & 16.42 \\
\hline & 2 & 47 & 46.01 & 21 & 47.73 & 22 & 32.84 \\
\cline { 2 - 8 } & 2 & 32 & 27.83 & 23 & 37.70 & 14 & 24.56 \\
\hline
\end{tabular}

Note: 1-young males, 2 - young females.

The research results from table 7 demonstrate that practically for all the polled students, cigarettes, beer, low-alcohol beverages, wine, sparkling wine and strong alcohol are fully affordable. The students also noted a high accessibility/affordability level of ecstasy, tranquilizers and other sedatives, as well as LSD or other hallucinogens.

\section{CONCLUSIONS}

Based on the results of the sociological study, which covered 446 students of medical, dental and non-medical departments, it was discovered that despite the high level of awareness, the students follow lifestyles, which do not help maintaining and improving their health.

The key problems are alcohol intake, irrational nutrition, lack of sleep and insufficient physical activity. This requires shaping modern methods of prevention and forming the students' responsible attitude towards their own health.

\section{SUMMARY}

The results of sociological study of 446 students of different years and departments of Uzhhorod National University and Ukrainian Dental Academy. The poll covered 217 medical department students (102 young males and 115 young females), 105 dental department students (44 young males and 61 young females) and 124 students of non-medical departments (67 young males and 57 young females).

The poll results witness a rather high awareness of students with regard to healthy lifestyle, safe behavior and health maintaining technologies. At the same time, the awareness of medical and dental students with regard to the said issues is higher than the awareness of the students of non-medical departments.

It was found that significant quantity of students lead lives, which do not help to maintain or improve their personal health. For instance, $52.27 \%$ of 
young male students of dental department, and $42.11 \%$ of young females and $40.29 \%$ of young males from non-medical sleep less than 4 hours a day. More than $70 \%$ of all departments regardless of their gender have wrong diets, both with regard to meals time and to foods range (except for young female students of medical department, who violate diet rules in $49.56 \%$ of cases). At the same time, more that $60 \%$ of all polled students use sweet carbonated beverages. All the polled students have insufficient physical activity. Less than $25 \%$ of all the polled students exercise daily, except for young male students from dental department, where $27.27 \%$ exercise daily. Regardless of department and gender, less than $30 \%$ of the polled students visit gym or swimming pool.

It was found that roughly $70 \%$ of the polled students had intercourse over the past 12 month prior to the poll. Most of the subjects have one sex partner. Three and more sex partners were reported by $34.38 \%$ of young males, who study at the dental department and $15.79 \%$ young male students, who study at non-medical departments. At the same time, only about $70 \%$ of subjects use condoms all the time during sexual intercourse.

Over the past 30 days, more than $90 \%$ of the polled subjects from medical departments and young male students from non-medical departments had alcohol. The lowest percentage of subjects who drank alcohol over the past 30 days was among dental students: $68.18 \%$ of young males and of $60.66 \%$ young females. In general, young male students prefer beer and strong drinks, while young females prefer wine/sparkling wine.

Out of those who used alcohol over the past 30 days most often reported intoxication was among young males $(70.45 \%)$ and young females $(31.15 \%)$, who study at the dental department and young male students from non-medical departments (32.84\%).

All students stated high accessibility level of cigarettes, alcohol and some other psychoactive substances.

The poll data form basis for modern prevention approaches formation and for shaping the students' responsible attitude towards their own health.

\section{REFERENCES}

1. Grebnyak N.P. Zdorov'e i obraz zhizni studentov / N.P. Grebnyak, V.P. Grebnyak, V.V. Mashinistov // Problemy sotsial'noy gigieny, zdravookhraneniya i istorii meditsiny. - 2007. - № 4. - S. 33-37.

2. Hooper L., Abdelhamid A., Moore H.J., Douthwaite W., Skeaff C.M., Summerbell C.D. Effect of reducing total fat intake on body weight: systematic review and meta-analysis of randomised controlled trials and cohort studies. British Medical Journal, 2012, no. 12, P. 12-15.

3. Baklykova A.V. Zdorov'e i obraz zhizni studentov-medikov // Molodoy uchenyy. - 2010. - № 5. T. 2. - S. 205-207. 
4. Sadvakasov T.M. Sravnitel'naya kharakteristika obraza zhizni lits molodogo vozrasta // T.M. Sadvakasov, Sh.D. Dzhaketaeva, G.A. Zhanalina, Zh.A. Aldanova, K.T. Abdrakhmanov, T.S. Sergaliev, D.B. Kulov // Meditsina i ekologiya. - 2015. - № 1(74). - S. 46-47.

5. Shagina I.R. Vliyanie uchebnogo protsessa na zdorov'e studentov // Astrakhanskiy meditsinskiy zhurnal. - 2010. - № 2. - S. 26-29.

6. Fats and fatty acids in human nutrition: report of an expert consultation. Food and Agricultural Organization of the United Nations / FAO Food and Nutrition. - Rome, Italy. - 2010. - P. 91.

7.Diet, nutrition and the prevention of chronic diseases: report of a Joint WHO/FAO Expert Consultation. World Health Organization - WHO Technical Report Series, No. 916. - Geneva, Switzerland, - 2003.

8. Gharkusha C.V. Kharakterystyka stanu zdorov'ja suchasnoji molodi v Ukrajini. Visnyk Chernigh. nac. ped. un-tu im. T.Gh. Shevchenka. Ser.: ped. nauky. Fiz. vykh. i sport. ChNGhGhU. 2013;1(107):92-5.

9. Ponomareva L.A. Analiz urovnya zdorov'ya studentov-medikov / L. A. Ponomareva, S. I. Dvoynikov // Zdorov'e sem'i XXI vek: mater. VI Mezhdunar. nauch. konf. - Perm', 2002. - S. 111-112.

10. Popkova O. S. Sotsial'no-gigienicheskie osobennosti formirovaniya zdorov'esberegayushchego povedeniya u studentov // Molodoy uchenyy. 2015. - №6.4. - S. 44-46. - URL https://moluch.ru/archive/86/16378/ (data obrashcheniya: 09.11.2019).

11. Zhdanova O.V. Rivenj internet-zalezhnosti studensjkoji molodi (za danymy sociologhichnogho doslidzhennja)/ O.V. Zhdanova, Gh.O.Slabkyj // Ukrajina. Zdorov'ja naciji. 2019. - \#2. - S.55-58

12. Baklykova A.V. Zdorov'e i obraz zhizni studentov-medikov. Molodoy uchenyy. 2010;5:205-7.

13. Ushakova Ya.V. Zdorov'e studentov i faktory ego formirovaniya/Ya.V. Ushakova // Vesnik Nizhegorodskogo universiteta im. N.I. Lobacheskogo. 2017. - №4 - S.197-202

14. Zhuravleva I.V., redaktor. Zdorov'e studentov: sotsiologicheskiy analiz. Institut sotsiologii RAN. Moskva; 2012. $252 \mathrm{~s}$.

\section{Information about the author:} Zhdanova O. V., orcid.org/0000-0002-4229-4604 Post-Graduate Student of Health Sciences

Uzhhorod National University 29, Mytna str., 88000, Uzhhorod, Ukraine 